\title{
HARMONISASI HUKUM DALAM ANTINOMI HUKUM (ANALISIS TERHADAP PENERAPAN PASAL 20 AYAT 2 HURUF B UNDANG-UNDANG REPUBLIK INDONESIA NOMOR 48 TAHUN 2009 TENTANG KEKUASAAN KEHAKIMAN)
}

\author{
Endrik Safudin, M.H
}

Institur Agama Islam Negeri Ponorogo

endriksafudin@iainponorogo.ac.id

\begin{abstract}
Antinomy is a condition that contradicts one another but cannot be separated because they both need each other. Likewise, the antinomic nature of the Supreme Court's role in conducting a judicial review of its own products, namely the Supreme Court Regulations. In the process of testing, the judge will be confronted with the principle that the judge is prohibited from examining cases related to himself (nemo judex idoneus in propia causa) and the principle that the judge is prohibited from rejecting the case presented to him (ius curia novit). This is how the antinomic nature has been formed from the beginning and harmony as a counterweight. By using descriptive-analysis, this research focuses on the harmonization of law in legal antinomies in the application of Article 20 paragraph 2 letter $b$ of the Republic of Indonesia Law Number 48 of 2009 concerning Judicial Power. The harmonization approach is intended to link the antinomic nature of the application of the article. With harmonization, it is hoped that the goals of increasing legal unity, legal certainty, justice (justice, gerechtigheid) and equality (equit, billijkeid), utility and legal clarity are expected, without obscuring and sacrificing legal pluralism.
\end{abstract}

Keywords: antinomy, harmonization, nemo judex, ius curia

ABSTRAK: Antinomi merupakan suatu kondisi saling bertentangan satu sama lain akan tetapi tidak dapat dipisahkan karena sama-sama saling membutuhkan. Begitu pula sifat antinomi peran Mahkamah Agung dalam melakukan uji materi terhadap produknya sendiri yaitu Peraturan Mahkamah Agung. Dalam proses pengujian tersebut hakim akan dihadapkan dengan asas hakim dilarang memeriksa perkara yang berkaitan dengan dirinya sendiri (nemo judex idoneus in propia causa) dan asas hakim dilarang menolak terhadap perkara yang diajukan kepadanya (ius curia novit). Begitulah sifat antinomi sejak awal sudah terbentuk dan harmoni 
sebagai penyeimbangnya. Dengan menggunakan deskriptif-analisis, penelitian ini fokus pada harmonisasi hukum dalam antinomi hukum pada penerapan pasal 20 ayat 2 huruf b Undang-Undang Repbuplik Indonesia Nomor 48 Tahun 2009 Tentang Kekuasaan kehakiman. Pendekatan harmonisasi dimaksudkan untuk menghubungkan sifat antinomi dalam penerapan pasal tersebut. Dengan harmonisasi diharapkan tetap tercapai tujuan peningkatan kesatuan hukum, kepastian hukum, keadilan (justice, gerechtigheid) dan kesebandingan (equit, billijkeid), kegunaan dan kejelasan hukum, tanpa mengaburkan dan mengorbankan pluralisme hukum.

Kata kunci: antinomi, harmonisasi, nemo judex, ius curia

\section{PENDAHULUAN}

Norma hukum hadir sebagai sebuah peraturan yang dibuat dan ditetapkan oleh penguasa negara, bersifat mengikat bagi setiap orang dan pelaksanaannya dapat dipaksaan oleh alat-alat negara. ${ }^{1} \mathrm{Di}$ dalam norma hukum terdapat asas-asas hukum yang menjadi akar dan pikiran dasar munculnya sebuah norma hukum. Asas-asas hukum sebagai meta-norma dibelakang norma yang mencakup kriteria nilai yang dikonkretisasikan kedalam norma hukum.

Di dalam norma hukum ada asas-asas tertentu yang mendukung kehidupan manusia. Asas-asas tertentu tersebut misalnya asas kenikmatan, asas realitas dan asas keserasian. Asasasas tersebut menghasilkan hasrat-hasrat tertentu, yakni di dalam kenyataan manusia, asas kenikmatan dan asas realitas merupakan antinomi. Artinya, kedua asas tersebut berpasangan dan bertentangan, yang harus ditanggulangi oleh asas keserasian. Maka, dalam proses kehidupan bathiniah manusia, asas kenikmatan dan asas realitas membuat jiwa manusia bagaikan suatu pendulum jam yang bergerak ke kiri dan ke kanan, namun dalam kedudukan konstan, karena pengaruh asas keserasian.2

Manusia lahir dengan potensi kodrat alamiahnya berupa cipta, karsa dan rasa. Dalam kodrat budaya, cipta berhubungan dengan ilmu dan logika, karsa dengan etika dan rasa dengan kesenian (estetika). Dalam dunia nilai, cipta akan berhubungan dengan

1 Endrik Safudin, Dasar-Dasar Ilmu Hukum (Malang: Setara Press, 2017), 63. Lihat juga Elly M. Setiadi dan Usman Kolip, Pengantar Sosiologi, Pemahaman Fakta Dan Gejala Permasalahan Sosial: Teori, Aplikasi Dan Pemecahannya, Cet ke II (Jakarta: Kencana Prenada Media Group, 2011), 133.

2 Purnadi Purbacaraka dan Soerjono Soekanto, Ikhtisar Antinomi Aliran Filsafat Sebagai Landasan Filsafat Hukum, 1 ed., cet. 2 (Jakarta: Rajawali, 1991), 2. 
pencarian nilai kebenaran, karsa dengan pencarian nilai keserasian sedangkan rasa dengan pencarian nilai keindahan. Disinilah akan nampak bahwa cipta dan rasa keduanya berpasangan dan bertentangan yang harus ditanggulangi oleh karsa. Begitulah sifat antinomi dalam diri manusia sejak awal sudah terbentuk dan harmoni sebagai penyeimbangnya.3

Disisi lain, norma hukum dihadirkan untuk kepentingan manusia yaitu jalan kesejahteraan manusia (sabili al-ibtida') serta jalan kebahagiaan di dunia dan akhirat (sa'adah fi al-dunya wa sa'adah fi al-akhirat). Sehingga norma hukum harus bersumber dan bertitik tolak pada penghormatan terhadap martabat manusia sebagai tujuan akhir dari hukum. Disinilah seakan ada pergerakan dinamis antara hukum dan potensi manusia itu sendiri.

Pada konteks ini, antinomi dapat ditemukan dalam UndangUndang Republik Indonesia Nomor 48 Tahun 2009 tentang Kekuasaan Kehakiman (selanjutnya disingkat UU Kehakiman). Dalam penelitian ini peneliti hanya akan fokus pada pasal 20 ayat 2 huruf b UU Kehakiman yang akan dikaitkan dengan eksistensi Peraturan Mahkamah Agung. Dalam pasal itu dijelaskan bahwa Mahkamah Agung berwenang "menguji peraturan perundangundangan di bawah undang-undang terhadap undang-undang". Peraturan dibawah undang-undang seperti peraturan pemerintah, peraturan presiden, peraturan gubernur dan peraturan bupati.4 Selain itu, peraturan dibawah undang-undang seperti peraturan yang ditetapkan oleh Majelis Permusyawaratan Rakyat, Dewan Perwakilan Rakyat, Dewan Perwakilan Daerah, Mahkamah Agung, Mahkmah Konstitusi, Badan Pemeriksan Keuangan, Komisi Yudisial, Bank Indonesia, Menteri, Badan, lembaga, atau komisi yang setingkat yang dibentuk dengan undang-undang atau pemerintah atas undangundang, dewan perwakilan rakyat daerah provinsi, gubernur, dewan

${ }^{3}$ Dalam kajian filsafat adalah sifat antinomi seperti spiritualisme/idealisme dan materialisme, indivdualisme dan kolektivisme, pragmatisme dan voluntarisme, ascetisisme dan hedonisme, empirisme dan intuisionisme, rasionalisme dan romantisisme. Lihat Ibid 2.

${ }^{4}$ Lihat pasal 7 Undang-Undang Nomor 12 Tahun 2011 tentang Pembentukan Peraturan Perundang-Undangan 
perwakilan rakyat daerah kabupaten/kota, bupati/walikota, kepala desa atau yang setingkat.5

Disini dapat dilihat bahwa Mahkamah Agung merupakan salah satu lembaga yang mempunyai kewenangan untuk mengeluarkan peraturan perundang-undangan dibawah undangundang yang disebut dengan Peraturan Mahkamah Agung (PERMA). Sehingga, ketika ada pengujian peraturan dibawah undang-undang merupakan kewenangan absolut dari Mahkamah Agung. Disinilah sifat antinomi muncul, yaitu asas dan norma yang terkandung di dalam pasal 20 ayat 2 huruf $b$ tersebut bertentangan dengan asas hakim tidak boleh memutus terhadap perkara yang memiliki hubungan dengan dirinya (nemo judex idoneus in propia causa).

Pertanyaannya adalah bukankah Peraturan Mahkamah Agung merupakam peraturan yang mengatur dirinya sendiri (Mahkamah Agung)?. apakah betul Mahkamah Agung tidak dapat menguji peraturan yang dibuatnya sendiri?. Apakah cara penyelesaian yang tepat terhadap sifat antinomi yang muncul dalam penerapan pasal 20 ayat 2 huruf b UU Kehakiman tersebut? Disinilah konsep harmonisasi hukum pada akhirnya muncul.

Berangkat dari kegelisahan inilah, penulis tertarik untuk melakukan penelitian dengan judul HARMONISASI HUKUM DALAM ANTINOMI HUKUM yang difokuskan terhadap penerapan Pasal 20 Ayat 2 Huruf B Undang-Undang Republik Indonesia Nomor 48 Tahun 2009 Tentang Kekuasaan Kehakiman.

Penelitian tentang harmonisasi hukum bukanlah hal yang baru dalam dunia akademik. Misalnya, artikel yang ditulis Kusnu Goesniadhie Slamet, Harmonisasi Hukum Dalam Perspektif Perundang-Undangan, ${ }^{6}$ artikel yang ditulis oleh Atya, Harmonisasi Hukum Internasional Pada Prinsip Common But Differentiated Resposnsibility Dalam Hukum Nasional, ${ }^{7}$ artikel yang ditulis oleh Mosgang Situmorang, Harmonisasi Hukum Nasional di Bidang

${ }^{5}$ Lihat pasal 8 Undang-Undang Nomor 12 Tahun 2011 tentang Pembentukan Peraturan Perundang-Undangan

6 Kusnu Goesniadhie Slamet, "Harmonisasi Hukum Dalam Perspektif Perundang-Undangan," Jurnal Hukum volume 11, no. 27 (September 2004).

7 Atya, "Harmonisasi Hukum Internasional Pada Prinsip Common But Differentiated Resposnsibility Dalam Hukum Nasional, jurnal kosmik hukum," Jurnal Kosmik Hukum Volume 19, no. 1 (Januari 2019). 
Korupsi Dengan United Nations Convention Against Corruption. ${ }^{8}$ Namun, penelitian ini mempunyai karakteristik yang berbeda dengan penelitian yang sudah ada yaitu harmonisasi dalam antimoni dalam suatu peraturan perundang-undangan.

Dengan menggunakan descriptive-analyses, penelitian ini membahas harmonisasi dalam antinomi terhadap penerapan Pasal 20 Ayat 2 Huruf B Undang-Undang Republik Indonesia Nomor 48 Tahun 2009 Tentang Kekuasaan Kehakiman. Dalam penerapan pasal tersebut yaitu pengujian peraturan perundang-undangan dibawah undang-undang dalam hal ini PERMA, maka, ada dua unsur yang saling bertentangan, namun kedua unsur tersebut tidak saling meniadakan. Dua unsur tersebut adalah asas hakim dilarang memeriksa perkara yang memiliki hubungan dengan dirinya (nemo judex idoneus in propia causa). Disisi lain, hakim dilarang mencegah terhadap perkara yang diajukan kepadanya (ius curia novit). Karena itulah, untuk mewujudkan itu membutuhkan suatu harmonisasi dalam penerapan pasal tersebut.

\section{KONSEP HARMONISASI HUKUM}

Secara etimologis, Harmonisasi merujuk pada cara yang berawal dari suatu usaha, untuk mengarah atau merealisasi sistem harmoni. Harmoni juga memiliki makna keselarasan, kecocokan, keserasian, keseimbangan yang menggembirakan. Secara makna psikologis, harmonisasi dimaknakan sebagai keseimbangan dan kesesuaian aspek-aspek di dalam perasaan, alam pikiran dan perilaku individu, sehingga tidak terbentuk hal-hal kegentingan yang lewat batas. ${ }^{9}$

Menurut Stammler" A just law aims at harmonizing individual purposes with that of society". Asas-asas hukum yang adil melingkupi harmonisasi antara kehendak, arah dan kepentingan perorangan, dengan kehendak, arah dan kepentingan umum. Kehendak dan arah serta kepentingan terdiri dari dua bagian, yaitu sama-sama menghormati dan partisipasi. ${ }^{10}$

8 Mosgang Situmorang, "Harmonisasi Hukum Nasional di Bidang Korupsi Dengan United Nations Convention Against Corruption," Jurnal Rechtsvinding:Media Pembinaan Hukum Nasional Volume 3, no. 3 (Desember 2014).

${ }^{9}$ Kusnu Goesniadhie Slamet, Harmonisasi Hukum Dalam Perspektif PerundangUndangan; Lex Specialis Suatu Masalah (Surabaya: JP Books, 2006), 59.

${ }^{10} \mathrm{Ibid}, 65$. 
Menurut J. M. Sinclair, dalam Collins Cobuild Dictionary (1991) terdapat kata harmonious dan harmonize dengan penjabaran yaitu: A relationship, agreement etc. that is harmonious is friendly and peaceful.Things which are harmonious have parts which make up an attractive whole and which are in proper proportion to each other When people harmonize, they agree about issues or subjects in a friendly, peaceful ways; suitable, reconcile. If you harmonize two or morw things, they fit in with each other is part of a system, society etc. ${ }^{11}$

Dari pengertian diatas dapat ditarik unsur-unsur harmonisasi, yaitu: (i) terdapat hal-hal yang berlawanan; (ii) menyerasikan hal-hal yang berlawanan secara proporsional agar menghasilkan suatu sistem; (iii) suatu usaha untuk mengkonkretkan keselarasan, kesesuaian, keserasian, kecocokan, dan keseimbangan; dan (iv) kerja sama antara beragam faktor yang sedemikian rupa, hingga faktorfaktor tersebut menciptakan kepaduan yang luhur.

Di dalam kepustakaan hukum di Netherland, Konsep harmonisasi hukum dicetuskan oleh Jan Micheil Otto dalam Implementation of Environmental Law: Harmonization, Environmental Management and Enforcement by The Courts, With Referances to Indonesia and The Netherland.

"When unnecessary incongruties between different elements of legal sistem which pertain to the same subject, an effort for harmonization can be made. This is such adaption of those elements that the incongruties are removed, that a better result is obtained, while the respective identities of those elements are kept in tach...."

L.M. Gandhi dalam "Harmonisasi Hukum Menuju Hukum Responsif" yang mencuplik buku Tussen Eenheid En Verscheidenheid: Opstellen Over Harmonisatie Instaaat En Bestuurecht (1988) menjelaskan bahwa harmonisasi dalam hukum yaitu melingkupi penyelarasan peraturan perundang-undangan, keputusan pemerintah, keputusan hakim, sistem hukum dan prinsip-prinsip hukum dengan tujuan peningkatan kesatuan hukum, kepastian hukum, keadilan (justice, gerechtigheid) dan kesederajatan (equit, billijkeid), kemanfaatan dan

11 L.M. Gandhi, "Harmonisasi Hukum Menuju Hukum yang Responsif" (Makalah yang disampaikan pada Pidato Pengukuhan Guru Besar Tetap FH-UI, 1995). 
transparansi hukum, tanpa memudarkan dan memusnahkan pluralisme hukum apabila diperlukan. ${ }^{12}$

Badan Pembinaan Hukum Nasional dalam buku yang ditulis oleh Moh. Hasan Wargakusumah dan kawan-kawan menjelaskan harmonisasi hukum merupakan aktivitas ilmiah untuk mengarah pada proses pengharmonisasian tertulis yang membidik baik pada nilai-nilai filosofis, sosiologis, ekonomis maupun yuridis. ${ }^{13}$ Ketiadaan harmonisasi dalam sistem hukum hendak membentuk kondisi tidak terjaminnya kepastian hukum yang bisa melahirkan gangguan dalam kehidupan bermasyarakat, ketidaktertiban dan rasa tidak dilindungi. Di dalam perspektif seperti itu ihwal kepastian hukum akan dinikmati seperti hajat yang hanya bisa terbentuk melewati harmonisasi sistem hukum. ${ }^{14}$

Dengan seperti itu, harmonisasi hukum seperti suatu proses keselarasan dalam perwujudan dan penegakan peraturan perundangundangan untuk menyelesaikan perbedaan, pertentangan dan kejanggalan diantara kaidah-kaidah hukum dalam peraturan atau antar peraturan perundang-undangan seperti subsistem di dalam bentuk sistem hukum. Harmonisasi hukum akan membentuk sistem hukum yang harmonis. Artinya, akan terbentuk sistem hukum yang selaras, serasi, seimbang, terintegrasi dan konsisten dalam pembentukan dan penegakannya. Sehingga, tujuan hukum untuk kemaslahatan manusia akan mudah tercapai.

\section{KONSEP ANTINOMI HUKUM}

Antinomi adalah kondisi yang bertentangan satu sama lain (merupakan konflik antar unsur), namun tidak bisa dipisahkan karena sama-sama saling memerlukan. Dengan kata lain antinomi adalah konflik antara dua unsur, tetapi kedua-duanya membutuhkan satu sama lain. ${ }^{15}$ Menurut Fockema, antinomi diartikan sebagai dua

12 Gandhi.L.M. Gandhi, Harmonisasi Hukum Menuju Hukum yang Responsif, Makalah, yang disampaikan pada Pidato Pengukuhan Guru Besar Tetap FH-UI, 1995 dalam Suhartono, Harmonisasi Peraturan Perundang-Undangan Dalam Pelaksanaan Anggaran Belanja Negara (Solusi Penyerapan Anggaran Belanja Negara Yang Efisien, Efektif Dan Akuntabel), Tesis (Jakarta: Universitas Indonesia, 2011), 95.

${ }^{13} \mathrm{Ibid}, 94$.

14 Slamet, Harmonisasi Hukum Dalam Perspektif Perundang-Undangan; Lex Specialis Suatu Masalah, 100.

15 Wantu Fence M., “Antinomi Dalam Penegakan Hukum Oleh Hakim,” Mimbar Hukum, 3, Volume 19 (Oktober 2007): 389-90. 
aturan atau lebih yang saling bertentangan, sehingga penyelesaianya wajib dicari melalui tafsir. Antinomi adalah dua hal yang berlainan namun saling menyempurnakan. Ketika menghadapi antinomi, seorang hakim harus bisa menciptakan keseimbangan atau keselarasan. ${ }^{16}$

Sebagai hasil perenungan nilai, norma hukum dalam implementasinya selalu ditemukan adanya bentrokan yang tidak dapat dihindarkan yaitu antara asas keadilan dengan asas kepastian hukum. Menurut Immanuel Kant yang dikutip oleh van Apeldoorn,, ${ }^{17}$ jika hukum diterapkan sama dengan bunyinya, maka keadilan akan semakin terdesak (summum ius summa in iuria). Sebaliknya, jika hukum diterapkan pada peristiwa tertentu, maka dirasakan semakin banyak mengingkari ketidakpastian.

Pada sejarahnya, antinomi dicetuskan oleh Immanuel Kant dalam Critique of Pure Reason, tentang perselisihan fundamental antara akal dan alam. ${ }^{18}$ Perselisihan tersebut selanjutnya membawa dampak yang kuat kepada metode berpikir hukum untuk menemukan keseimbangan di antara beraneka ragam hal yang kontradiktif, tetapi wajib tetap dirawat. Dari sinilah konsep antinomi pada hukum lahir seperti sebuah "konsep pertentangan" untuk menjadi tumpuan proses analitis pada norma-norma dan nilai-nilai dalam suatu aturan. Begitulah sifat antinomi dalam sebuah peraturan.

Berpijak dari pemikiran Kant, kemudian berkembang pula pemikiran antinomi dalam teori hukum, atau pun antinomy norma dalam suatu aturan hukum. Melanjutkan konsepsi yang dilaksanakan Kant, hukum diposisikan pada suatu kerangka esensial untuk memberi jawaban atas permasalahan apa tujuan hidup yang sebenarnya. Manusia selanjutnya berusaha menjawab persolan esensial tersebut, melewati sebuah proses dialektika, yang diilustrasikan Hegel lengkap dengan keretakan, fragmentasi, pertentangan dan aporia, dengan cita-cita bisa melahirkan suatu ide

16 Fockema Andreae, Kamus Istilah Hukum: Belanda-Indonesia, Cet. 1 (Jakarta: Binacipta, 1983), 32.

17 L.j. Van Apeldroon, Pengantar Ilmu Hukum (Bandung: PT. Pradnya Paramita, 2001), 13.

18 Lihat Immanuel Kant, Critique Of Pure Reason (Cambridge: Cambridge University Press, 2010). Lihat juga David Hume, A Treatise Of Human Nature (Auckland: The Floating Press, 2009). 
analitik yang dapat menjadi konklusi umum. ${ }^{19}$ Meskipun seperti itu, sampai sekarang peradaban barat belum pernah melahirkan kata sepakat mengenai tujuan hidup yang tertinggi, pada tataran teoritik sekalipun. ${ }^{20}$

Antinomi dalam teori hukum atau kaidah hukum, menurut Friedmann, adalah kontrakdiksi-kontradiksi yang terjadi sebagai dampak dari kedudukan alamiah hukum itu sendiri yang berada di antara nalar filsafat dan kebutuhan praktis politik-kepentingan. kelompok-kelompok intelektual hukum dibentuk dari penalaran filsafat yang lama dan holistik, disisi lain cita-cita keadilan di dalam hukum dikonstruksikan melewati sebuah mekanisme politik yang condong transaksional. ${ }^{21}$ Dampaknya, hukum tidaklah sesuatu yang terjadi secara alamiah, tetapi sebagai hasil-resultante dari berbagai proses internalisasi, intrusi dan negosiasi beraneka ragam kepentingan di antara fraksi-fraksi dan aktor-aktor di dalam masyarakat. ${ }^{22}$

W friedmann mengatakan, dalam perkembangan teori hukum sedikitnya memiliki enam antinomi di dalamnya, yaitu: individu dan alam semesta; kesukarelaan dan pengetahuan obyektif; akal dan intuisi; stabilitas dan perubahan; positivisme dan idealisme; kolektivisme dan individualisme; demokrasi dan otokrasi; internasionalisme dan nasionalisme; ${ }^{23}$

\section{KONSEP NORMA HUKUM}

Norma hukum adalah peraturan hidup yang dibuat oleh penguasa negara. Norma hukum berisi tentang peraturan yang bersifat mengikat bagi setiap orang dan pelaksanaannya dapat dipaksakan oleh alat-alat negara. Karakteristik norma hukum bersifat

${ }^{19}$ Alan Norrie, "From Critical to Social-Legal Studies: Three Dialectics in Search of a Subject," Journal Social and Legal Studies, no. 9 (2000): 85, http://sls.sagepub.com/content/9/1/85..

${ }^{20}$ W Friedmann, Teori Dan Filsafat Hukum, Telaah Kritis Atas Teori-Teori Hukum, penerjemah Arifin, M, (Jakarta: Rajawali Pers, 1990), 2.

21 Ibid,

22 Zainal Arifin Mochtar, “Antinomi Dalam Peraturan Perundang-Undangan Di Indonesia," Jurnal Hasanuddin Law Review 1, no. issue 2 (Desember 2015): 321.

${ }^{23}$ Friedmann, Teori Dan Filsafat Hukum, Telaah Kritis Atas Teori-Teori Hukum, 2. 
memaksa dan bersanksi tegas. ${ }^{24}$ Karakteristik inilah yang membedakan norma hukum dengan norma kesusilaan, norma agama dan norma kesopanan. ${ }^{25}$ Persamaannya adalah norma-norma tersebut hadir untuk menjaga kepentingan manusia agar ketentraman dan ketertiban dalam masyarakat terpelihara dan terjamin. ${ }^{26}$

Sebuah norma (a norm), menurut Kelsen, is a rule expressing the fact that somebody ought to act in a certain way, without implying that anybody really "wants" the person to act that way" (Sebuah norma adalah sebuah peraturan yang menyatakan fakta bahwa seseorang memiliki keharusan untuk bertindak menurut cara tertentu, tanpa menyiratkan arti bahwa seseorang sesungguhnya "menginginkan" atau "menghendaki" orang itu berbuat menurut cara tersebut). ${ }^{27}$

Dari pemikiran Kelsen ini dapat membentuk sebuah konsep hubungan antara peraturan hukum dan hukum alam yaitu peraturan hukum yang berkutat pada segi keharusan (das sollen) dan hukum alam yang berkutat pada segi kenyataan (das sein).

Norma sebagai pelembagaan nilai-nilai baik dan buruk dalam wujud tata aturan yang memuat kebolehan, anjuran, atau perintah. Anjuran atau perintah bisa berisi norma yang berkarakter positif atau negatif, sehingga meliputi norma anjuran untuk melaksanakan atau tidak melaksanakan sesuatu, dan norma perintah untuk melaksanakan atau tidak melaksanakan sesuatu. ${ }^{28}$ Hal ini untuk memenuhi tujuan hukum yaitu kedamaian hidup antarpribadi (het recht wil de vrede). Karena itu, sering dikatakan bahwa penegak hukum itu bekerja "to preserve peace". ${ }^{29}$ Keadaan damai sebagai tujuan akhir norma hukum terletak pada kesimbangan antara dimensi lahiriah dan batiniah. Hasil akhirnya, terwujud keseimbangan antara ketertiban dan ketentraman, antara keamanan dan ketenangan. ${ }^{30}$

24 Safudin, Dasar-Dasar Ilmu Hukum, 63. Lihat juga Setiadi dan Kolip, Pengantar Sosiologi, Pemahaman Fakta Dan Gejala Permasalahan Sosial: Teori, Aplikasi Dan Pemecahannya, 133.

25Safudin, Dasar-Dasar Ilmu Hukum, 59-63.

26 Endrik Safudin, Pengantar Ilmu Hukum (Malang: Setara Press, 2020), 144.

27 Hans Kelsen, General Theory of Law and State (Cambridge, Massachusetts: Harvard University Press, 1949), 35.

28 Jimly Asshiddiqie, Perihal Undang-Undang (Jakarta: Rajawali Pers, 2010), 1.

${ }^{29}$ Garner Bryan A., ed., Black law dictionary (ST. Paul, Minn: West Group, 1968).

${ }^{30}$ Asshiddiqie, Perihal Undang-Undang, 3. 


\section{KONSEP PERATURAN PERUNDANG-UNDANGAN}

Istilah perundang-undangan, menurut A. Hamid. S Attamimi, diartikan sama dengan wetgeving dan gesetzgebung, yaitu keseluruhan peraturan yang dibentuk oleh lembaga-lembaga negara atau pemerintah dan diartikan juga sebagi proses/kegiatan pembentukan peraturan tersebut. ${ }^{31}$ Sedangkan peraturan perundang-undangan menurut Bagir Manan, adalah sebagai hukum positif tertulis yang dibuat, ditetapkan, atau dibentuk pejabat atau instansi yang berwenang atau berlandaskan ketentuan perundang-undangan tertentu dalam wujud tertulis yang memuat tingkah laku atau mengikat (secara) umum. ${ }^{32}$

Peraturan Perundang-undangan merupakan peraturan tertulis bersifat mengikat secara umum dan dibentuk atau ditetapkan oleh lembaga negara atau pejabat yang berwenang dengan prosedur yang ditetapkan sesuai dengan peraturan perundang-undangan. Bentukbentuk peraturan perundang-undangan seperti undang-undang, peraturan pemerintah pengganti undang-undang, peraturan pemerintah, peraturan daerah provinsi dan peraturan daerah kabupaten. ${ }^{33}$ Selain itu, ada peraturan yang ditetapkan oleh Majelis Permusyawaratan Rakyat, Dewan Perwakilan Rakyat, Dewan Perwakilan Daerah, Mahkamah Agung, Mahkmah Konstitusi, Badan Pemeriksan Keuangan, Komisi Yudisial, Bank Indonesia, Menteri, Badan, lembaga, atau komisi yang setingkat yang dibentuk dengan undang-undang atau pemerintah atas undang-undang, dewan perwakilan rakyat daerah provinsi, gubernur, dewan perwakilan rakyat daerah kabupaten/kota, bupati/walikota, kepala desa atau yang setingkat. ${ }^{34}$

Sedangkan hierarki peraturaan perundang-undangan di atur dalam pasal 7 ayat (1) Undang-Undang Nomor 12 Tahun 2011 tentang Pembentukan Peraturan Perundang-Undangan dijelaskan bahwa jenis dan hierarki peraturan perundang-undangan terdiri atas:

31 A. Hamid S Attamimi, Teori Perundang-Undangan: Suatu Sisi Ilmu Pengetahuan Perundang-Undangan Indonesia yang Menjelaskan dan Menjernihkan Pemahaman, Pidato Pengukuhan Jabatan Guru Besar Tetap Pada Fakultas Hukum Universitas Indonesia (Jakarta, 1992).

32 Bagir Manan, Hukum Positif Indonesia (Yogyakarta: FH UII Press, 2004), 41.

33 Safudin, Dasar-Dasar Ilmu Hukum, 33.

34 Lihat pasal 8 ayat 1 Undang-Undang Nomor 12 Tahun 2011 Tentang Pembentukan Peraturan Perundang-Undangan 
a. Undang-Undang Dasar Negara Republik Indonesia Tahun 1945;

b. Ketetapan Majelis Permusyawaratan Rakyat;

c. Undang-undang/peraturan pemerintah pengganti undangundang;

d. Peraturan pemerintah;

e. Peraturan presiden;

f. Peraturan daerah provinsi; dan

g. Peraturan daerah kabupaten/kota.

Di dalam pembuatan dan pemberlakuan peraturan perundang-undangan juga terdapat beberapa asas hukum seperti asas lex posterior derogat lege priori (peraturan yang bertindak kemudian menghapuskan peraturan terdahulu), Asas lex superior derogat legi inferior (peraturan yang dibentuk oleh penguasa yang lebih tinggi memiliki kedudukan lebih tinggi), Asas lex specialis derogat legi generalis (peraturan yang khusus menyingkirkan peraturan yang bersifat umum). ${ }^{35}$

KONSTRUKSI ANTINOMI DALAM PENERAPAN PASAL 20 AYAT 2 HURUF B UNDANG-UNDANG REPUBLIK INDONESIA $\begin{array}{llllll}\text { NOMOR } & 48 & \text { TAHUN } 2009 & \text { TENTANG } & \text { KEKUASAAN }\end{array}$ KEHAKIMAN

Dalam pasal 20 ayat (2) huruf b Undang-Undang Nomor 48 Tahun 2009 tentang Kekuasaan Kehakiman menegaskan bahwa Mahkamah Agung berwenang "menguji peraturan perundang-undangan di bawah undang-undang terhadap undang-undang".

Penjelasannya pasal 20 ayat (2) huruf b diatas yaitu:

"ketentuan ini mengatur mengenai hak uji mahkamah agung terhadap peraturan perundang-undangan yang lebih rendah dari undang-undang. hak uji dapat dilakukan baik terhadap materi muatan ayat, pasal, dan/atau bagian dari peraturan perundangundangan yang bertentangan dengan peraturan perundangundangan yang lebih tinggi maupun terhadap pembentukan peraturan perundang-undangan"

Dari rumusan pasal 20 diatas dapat diketahui bahwa Mahkamah Agung mendapatkan kekuasaan atributif ${ }^{36}$ berupa hak uji

35 Safudin, Pengantar Ilmu Hukum, 23.

36 Kekuasaan atributif adalah kekuasaan yang diberikan langsung oleh konstitusi atau undang-undang. Menurut Philipus M. Hadjon dalam paper yang 
materi peraturan perundang-undangan dibawah undang-undang baik berupa materi yang memuat ayat, pasal dan/atau bagian dari peraturan perundang-undangan yang berlawanan dengan peraturan perundang-undangan yang lebih tinggi maupun pada pembentukan peraturan perundang-undangan.

Selanjutnya, apa saja bentuk peraturan perundang-undangan dibawah undang-undang yang menjadi hak uji Mahkamah Agung?. Berdasarkan pasal 7 ayat (1) Undang-Undang Nomor 12 Tahun 2011 tentang Pembentukan Peraturan Perundang-Undangan dijelaskan bahwa jenis dan hierarki peraturan perundang-undangan terdiri atas:

a. Undang-Undang Dasar Negara Republik Indonesia Tahun 1945;

b. Ketetapan Majelis Permusyawaratan Rakyat;

c. Undang-undang/peraturan pemerintah pengganti undangundang;

d. Peraturan pemerintah;

e. Peraturan presiden;

f. Peraturan daerah provinsi; dan

g. Peraturan daerah kabupaten/kota."

Dari rumusan pasal 7 ayat (1) diatas dapat diketahui bahwa yang termasuk peraturan yang dibawah undang-undang adalah peraturan pemerintah, peraturan presiden, peraturan daerah provinsi dan peraturan daerah kabupaten/kota.

Selain peraturan perundang-undangan dibawah undangundang yang diatur dalam rumusan diatas terdapat peraturan yang diatur dalam pasal 8 ayat (1) yang dijelaskan bahwa:

Jenis Peraturan Perundang-undangan selain sebagaimana dimaksud dalam Pasal 7 ayat (1) mencakup peraturan yang ditetapkan oleh Majelis Permusyawaratan Rakyat, Dewan Perwakilan Rakyat,

berjudul discretionary power dan asas-asas umum pemerintahan yang baik (AAUPB) yang disampaikan pada seminar nasional aspek pertanggungjawaban pidana dalam kebijakan publik dari tindak pidana korupsi, Semarang, 6-7 mei 2004, hlm. 1, menjelaskan bahwa atribusi merupakan pemberian kewenangan oleh pembentuk undang-undang kepada suatu organ pemerintahan baik yang sudah ada maupun yang baru sama sekali. Atribusi merujuk kepada kewenangan yang asli atas prinsip ketentuan hukum tata negara. Suatu atribusi adalah wewenang untuk menghasilkan keputusan (besluit) yang langsung berpangkal kepada undang-undang dalam arti materiil. Rumusan lain menjelaskan bahwa atribusi adalah pembentukan wewenang tertentu dan pemberiannya kepada organ tertentu. Yang bisa membentuk wewenang adalah organ yang berwenang berlandaskan peraturan perundang-undangan 
Dewan Perwakilan Daerah, Mahkamah Agung, Mahkamah Konstitusi, Badan Pemeriksa Keuangan, Komisi Yudisial, Bank Indonesia, Menteri, badan, lembaga, atau komisi yang setingkat yang dibentuk dengan Undang-Undang atau Pemerintah atas perintah Undang-Undang, Dewan Perwakilan Rakyat Daerah Provinsi, Gubernur, Dewan Perwakilan Rakyat Daerah Kabupaten/Kota, Bupati/Walikota, Kepala Desa atau yang setingkat

Dari rumusan pasal 8 ayat (1) diatas dapat diketahui bahwa ada peraturan yang ditetapkan oleh Mahkamah Agung. Sehingga peraturan yang ditetapkan Mahkamah Agung merupakan peraturan yang tercakup dalam kategori peraturan perundang-undangan dibawah undang-undang.

Peraturan Mahkamah Agung (PERMA) merupakan peraturan yang dimaksudkan untuk mengatur dirinya sendiri (Mahkamah Agung) dan badan peradilan dibawahnya dalam lingkungan peradilan umum, lingkungan peradilan agama, lingkungan peradilan militer, lingkungan peradilan tata usaha negara. Kewenangan menetapkan PERMA ini juga sejalan dengan atribusi yang diberikan oleh undang-undang yaitu pasal pasal 20 huruf c Undang-Undang Nomor 48 tahun 2009 tentang kekuasaan kehakiman. Sedangkan pasal 8 ayat (2) Undang-Undang Nomor 12 Tahun 2011 tentang Pembentukan Peraturan Perundang-Undangan dijelaskan bahwa:

Peraturan Perundang-undangan sebagaimana dimaksud pada ayat (1) diakui keberadaannya dan mempunyai kekuatan hukum mengikat sepanjang diperintahkan oleh Peraturan Perundang-undangan yang lebih tinggi atau dibentuk berdasarkan kewenangan.

Kewenangan Mahkamah Agung dalam menetapkan peraturan sebagai penentu peletakan fungsi pengaturan atau regelende functie pada diri Mahkamah Agung sendiri telah tegas dijelaskan pada pasal 79 Undang-Undang Nomor 14 Tahun 1985 tentang Mahkamah Agung yaitu "Mahkamah Agung dapat mengatur lebih lanjut hal-hal yang diperlukan bagi kelancaran penyelenggaraan peradilan apabila terdapat halhal yang belum cukup diatur dalam undang-undang ini.".

Dengan seperti itu, peraturan Mahkamah Agung sebagai sesuatu hal yang sah dan realistis, karena secara objektif dapat dikatakan bahwa tidak akan ada ketentuan peraturan perundangundangan yang seterusnya mampu memberikan pemecahan hukum 
yang muncul sebagai dampak dari perubahan sosial yang cepat. ${ }^{37}$ Karena itulah menurut Yahya Harahap, kapanpun dan dimanapun tidak pernah manusia bisa membentuk dan menciptakan perundangundangan yang lengkap. Dilihat dari pendapat J.H.A. Logemann tentang syarat dan kategori dari suatu perundang-undangan, maka Peraturan Mahkamah Agung ini hanya berlaku secara internal, karena tidak memuat norma yang mengikat bagi pihak luar dari lembaga pengadilan, tetapi hanya para hakim yang mengadili suatu perkara pada lingkungan Mahkamah Agung.

Oleh karena itu, untuk menghasilkan terwujudnya kesatuan pendapat hukum (unified legal opinion) dan keserasian kerangka kerja hukum (unified legal frame work), secara obyektif lebih tepat apabila Mahkamah Agung mengeluarkan suatu peraturan. ${ }^{38}$ Peraturan yang dikeluarkan Mahkamah Agung menjadi sangat penting ketika menghadapi suatu keadaan yang belum diatur oleh pembuat undang-undang sehingga terhindar dari kekosongan atau keterbelakangan hukum yang terkandung di dalam suatu peraturan perundang-undangan. Peraturan Mahkamah Agung akan menjadi sebuah sarana guna memperlancar tugas para hakim di dalam melakukan proses penemuan hukum (rechtvinding). Jadi, peraturan Mahmakah Agung pada prinsipnya merupakan bentuk pengaturan yang berisi ketentuan bersifat hukum acara. ${ }^{39}$

Dari uraian kewenangan Mahkamah Agung diatas, dapat ditarik sebuah pernyataan yaitu: Mahkamah Agung memiliki wewenang untuk menguji peraturan perundang-undangan di bawah undang-undang termasuk peraturan Mahkamah Agung (PERMA). Artinya Mahkamah Agung akan menguji peraturan yang ditetapkan Mahkamah Agung sendiri. Sehingga, pernyataan tersebut membawa sebuah pertanyaan yaitu ketika Mahkamah Agung menguji peraturan yang dibuatnya sendiri apakah hal ini tidak terjadi konflik kepentingan (conflict of interest)?. Bukankah hakim dilarang

37 M. Yahya Harahap, Kekuasaan Mahkamah Agung Pemeriksaan Kasasi Dan Peninjauan Kembali Perkara Perdata, cetakan pertama (Jakarta: Sinar Grafika, 2008), 163-73.

$38 \mathrm{Ibid}, 167$.

39 Peraturan Mahkamah Agung adalah peraturan yang memuat ketentuan yang bersifat hukum acara seperti dimaksud pada lampiran keputusan ketua Mahkamah Agung RI Nomor 57/KMA/SK/1V/2016 tentang perubahan atas Keputusan Ketua Mahkamah Agung Republik Indonesia Nomor 271/KMA/SK/X/2013 Tentang Pedoman Penyusunan Kebijakan Mahkamah Agung Republik Indonesia. 
memeriksa perkara yang berhubungan dengan dirinya sendiri (nemo judex idoneus in propia causa)?. Disisi lain, hakim dilarang menolak terhadap perkara yang diajukan kepadanya karena hakim dianggap mengetahui semua hukum (ius curia novit).

Pernyataan dan pertanyaan diatas merupakan antinomi yaitu suatu kondisi yang bertentangan dan berlawanan satu sama lain, namun tidak saling meniadakan dan tidak dapat dipisahkan karena saling membutuhkan.

Prinsip hakim tidak boleh menolah memeriksa dan mengadili perakara ditegaskan dalam Pasal 10 Undang-Undang Nomor 48 Tahun 2009 tentang Kekuasaan Kehakiman sebagai berikut:

1) Pengadilan dilarang menolak untuk memeriksa, mengadili, dan memutus suatu perkara yang diajukan dengan dalih bahwa hukum tidak ada atau kurang jelas, melainkan wajib untuk memeriksa dan mengadilinya.

2) Ketentuan sebagaimana dimaksud pada ayat (1) tidak menutup usaha penyelesaian perkara perdata secara perdamaian."

Rumusan pasal 10 diatas menegaskan bahwa hakim harus menerima, memeriksa, mengadili dan memutus perkara yang diberikan kepadanya dan tidak boleh menghindar dengan dalih bahwa hukum tidak ada atau kurang jelas. yaitu: ${ }^{40}$

Disisi lain, hakim sebagai organ pengadilan dapat dikatakan

a. Dianggap mengetahui hukum;

b. Oleh sebab itu wajib memberi pelayanan kepada setiap pencari keadilan yang mengharap keadilan kepadanya;

c. Ketika hakim dalam memberi pelayanan mengakhiri sengketa, tidak menjumpai hukum tertulis, hakim wajib menjelajahi hukum tidak tertulis untuk memutus perkara berlandas hukum sebagai orang yang bijaksana dan bertanggungjawab penuh kepada Tuhan Yang Maha Esa, diri sendiri, masyarakat, bangsa dan negara.

Hakim dianggap mengetahui dan memahami segala hukum (ius curia novit/curia novit jus) mempunyai implikasi bahwa hakim yang berwenang menetapkan hukum objektif mana yang harus dikonkretkan (toepassing) sesuai dengan materi pokok perkara yang

40 M. Yahya Harahap, Hukum Acara Perdata Tentang Gugatan, Persidangan, Penyitaan, Pembuktian dan Putusan Pengadilan (Jakarta: Sinar Grafika, 2016), 821. 
mengikat hubungan hukum pihak-pihak yang berperkara dalam konkreto. ${ }^{11}$ Sebab kewenangan menciptakan dan mempergunakan hukum objektif, bukan hak dan kewenangan para pihak, melainkan kewajiban dan kewenangan mutlak hakim. Para pihak tidak mempunyai kewajiban menujukkan hukum apa yang harus diterapkan, sebab hakim dianggap mengetahui segala hukum (ius curia novit/curia novit ius). ${ }^{42}$ Jadi, pasal 10 Undang-Undang Nomor 48 Tahun 2009 tentang Kekuasaan Kehakiman dan adagium ius curia novit/curia novit ius bermakna bahwa hakim dianggap memahami hukum sehingga pengadilan tidak boleh menghindar memeriksa dan mengadili perkara.

Sedangkan asas nemo judex idoneus in propia causa (niemand is geschikt om als rechter in zijn eigen zaak op te treden, bahwa tidak seorangpun dapat menjadi hakim dalam perkaranya sendiri) merupakan perwujudan imparsialitas (ketidakberpihakan/impartiality) hakim sebagai pemberi keadilan. Asas trsebut pada hakikatnya melekat pada fungsi hakim, hakim tidak boleh memihak terhadap perkara yang diajukan kepadanya. karena itulah hakim wajib bersikap merdeka dari pengaruh apapun. Sebab itulah, imparsialitas proses peradilan hanya dapat dilakukan, jika hakim dapat melepaskan diri dari konflik kepentingan atau faktor semangat pertemanan (collegial) atau semangat kekeluargaan dengan pihak yang berperkara, karenanya hakim harus mengundurkan diri apabila ada potensi menghilangkan sifat imparsialitas.

Prinsip Imparsialitas tercantum dalam pasal 1 angka 1 Undang-Undang Republik Indonesia Nomor 48 Tahun 2009 Tentang Kekuasaan Kehakiman yang menegaskan bahwa "kekuasaan kehakiman adalah kekuasaan negara yang merdeka untuk menyelenggarakan peradilan guna menegakkan hukum dan keadilan berdasarkan pancasila dan UndangUndang Dasar Negara Republik Indonesia Tahun 1945, demi terselenggaranya Negara Hukum Republik Indonesia.". Kata "merdeka" dalam pasal tersebut menegaskan prinsip imparsialitas yang dimaksudkan bahwa kekuasaan kehakiman harus lepas dari konflik

41 R. Soepomo, Hukum Acara Perdata Pengadilan Negeri (Jakarta: Pradnya Paramita, 1993), 85.

$42 \mathrm{Ibid}, 85$. 
kepentingan atau faktor semangat pertemanan (collegial) atau semangat kekeluargaan dengan pihak yang berperkara.

Prinsip imparsialitas ditegaskan juga dalam beberapa pasal dalam Undang-Undang Republik Indonesia Nomor 48 Tahun 2009 Tentang Kekuasaan Kehakiman yaitu:

a. Pasal 3 ayat (2), yaitu "segala campur tangan dalam urusan peradilan oleh pihak lain di luar kekuasaan kehakiman dilarang, kecuali dalam halhal sebagaimana dimaksud dalam Undang-Undang Dasar Negara Republik Indonesia Tahun 1945".

b. Pasal 4 ayat (1), yaitu "pengadilan mengadili menurut hukum dengan tidak membeda-bedakan orang"

c. Pasal 17 yaitu:

(3) Seorang hakim wajib mengundurkan diri dari persidangan apabila terikat hubungan keluarga sedarah atau semenda sampai derajat ketiga, atau hubungan suami atau istri meskipun telah bercerai, dengan ketua, salah seorang hakim anggota, jaksa, advokat, atau panitera.

(4) Ketua majelis, hakim anggota, jaksa, atau panitera wajib mengundurkan diri dari persidangan apabila terikat hubungan keluarga sedarah atau semenda sampai derajat ketiga, atau hubungan suami atau istri meskipun telah bercerai dengan pihak yang diadili atau advokat.

(5) Seorang hakim atau panitera wajib mengundurkan diri dari persidangan apabila ia mempunyai kepentingan langsung atau tidak langsung dengan perkara yang sedang diperiksa, baik atas kehendaknya sendiri maupun atas permintaan pihak yang berperkara."

Undang-Undang Nomor 14 Tahun 1985 Tentang Mahkamah Agung sendiri juga mengatur imparsialitas hakim, khususnya dalam pasal 10 yang menegaskan bahwa Hakim Agung tidak boleh merangkap menjadi:

a. Pelaksana putusan Mahkamah Agung;

b. Wali, pengampu, dan pejabat yang berkaitan dengan suatu

perkara yang akan atau sedang diperiksa olehnya;

c. Penasihat hukum;

d. Pengusaha 
Selain pasal 10 Undang-Undang Nomor 14 Tahun 1985 Tentang Mahkamah Agung, prinsip imparsialitas dijelaskan dalam pasal 41 yang menegaskan bahwa:

(1) Seorang Hakim wajib mengundurkan diri dari suatu persidangan apabila terdapat hubungan keluarga sedarah atau semenda sampai derajat ketiga atau hubungan suami atau isteri meskipun sudah bercerai dengan salah seorang Hakim Anggota atau Panitera pada Majelis yang sama dimaksudkan Pasal 40 ayat (1).

(2) Seorang Hakim atau Panitera wajib mengundurkan diri dari persidangan apabila terikat hubungan keluarga sedarah atau semenda sampai derajat ketiga atau hubungan suami atau isteri meskipun sudah bercerai dengan Penuntut Umum, Oditur Militer, Terdakwa, Penasihat Hukum, Tergugat atau Penggugat.

(3) Hubungan keluarga sebagaimana dimaksudkan ayat (1) dan ayat (2) berlaku juga antara Hakim Agung dan/atau Panitera Mahkamah Agung dengan Hakim dan/atau Panitera Pengadilan Tingkat Pertama serta Hakim dan/atau Panitera Pengadilan Tingkat Banding, yang telah mengadili perkara yang sama.

(4) Jika seorang Hakim yang memutus perkara dalam tingkat pertama atau tingkat banding, kemudian telah menjadi Hakim Agung, maka Hakim Agung tersebut dilarang memeriksa perkara yang sama.

(5) Hakim atau Panitera sebagaimana dimaksudkan ayat (1), ayat (2), ayat (3), dan ayat (4) harus diganti, dan apabila tidak diganti atau tidak mengundurkan diri sedangkan perkara telah diputus, maka putusan tersebut batal dan perkara tersebut wajib segera diadili ulang dengan susunan Majelis yang lain.

Sedangkan asas nemo judex idoneus in propia causa dijelaskan secara tegas dalam Pasal 42 (1) Undang-Undang Nomor 14 Tahun 1985 Tentang Mahkamah Agung yaitu “Seorang Hakim tidak diperkenankan mengadili suatu perkara yang ia sendiri berkepentingan, baik langsung maupun tidak langsung."

Dari uraian di atas dapat diketahui konstruksi Antinomi dalam penerapan pasal 20 ayat 2 huruf b Undang-Undang Republik Indonesia Nomor 48 Tahun 2009 Tentang Kekuasaan Kehakiman. Sehingga dapat dibuat pernyataan yaitu Pertama, penerapan pasal 20 ayat 2 huruf $b$ Undang-Undang Republik Indonesia Nomor 48 Tahun 2009 Tentang Kekuasaan Kehakiman yaitu kewenangan Mahkamah Agung untuk menguji peraturan perundang-undangan di bawah 
undang-undang termasuk PERMA. Kedua, antinomi penerapan pasal 20 ayat 2 huruf b Undang-Undang Republik Indonesia Nomor 48 Tahun 2009 Tentang Kekuasaan Kehakiman adalah pasal 10, pasal 1 angka (1), pasal 3 ayat (2), pasal 4 ayat (1), pasal 17 ayat (3), pasal 17 ayat (4), pasal 17 ayat (5) yang didalamnya mencakup asas nemo judex idoneus in propia causa dan asas ius curia novit. Selain itu, pasal 10, pasal 41 dan Pasal 42 (1) Undang-Undang Nomor 14 Tahun 1985 Tentang Mahkamah Agung juga menjadi antinomi penerapan pasal 20 ayat 2 huruf b Undang-Undang Republik Indonesia Nomor 48 Tahun 2009 Tentang Kekuasaan Kehakiman. Namun, tidak saling meniadakan dan tidak dapat dipisahkan karena saling membutuhkan.

\section{KONSEP HARMONISASI HUKUM DALAM PENERAPAN PASAL 20 AYAT 2 HURUF B UNDANG-UNDANG REPUBLIK INDONESIA NOMOR 48 TAHUN 2009 TENTANG KEKUASAAN KEHAKIMAN}

Harmonisasi hukum muncul sebagai respon adanya antinomi hukum. Ketika antinomi hukum adalah suatu keadaan yang kontradiktif satu sama lain, tidak bisa dipisahkan, tiada saling meniadakan dan saling memerlukan maka harmonisasi hukum hadir sebagai relasi dua unsur yang bertentangan tersebut.

Antinomi menurut Fockema diartikan sebagai dua aturan atau lebih yang saling bertentangan, sehingga penyelesaiannya wajib dicari melalui tafsir. Antinomi adalah dua hal yang berlainan namun saling menyempurnakan. Ketika menghadapi antinomi, seorang hakim harus bisa menciptakan keseimbangan atau keselarasan. ${ }^{43}$ Keseimbangan dan kesesuaian unsur-unsur dalam perasaan, alam pikiran dan perbuatan individu, sehingga tidak terjadi hal-hal kegentingan yang lewat batas. ${ }^{44}$

Pada konteks penerapan Pasal 20 Ayat 2 Huruf B UndangUndang Republik Indonesia Nomor 48 Tahun 2009 Tentang

43 Andreae, Kamus Istilah Hukum: Belanda-Indonesia, 32.

${ }^{4}$ Slamet, Harmonisasi Hukum Dalam Perspektif Perundang-Undangan; Lex Specialis Suatu Masalah, 59. 
Kekuasaan Kehakiman telah ditemukan dua pernyataan sebagai berikut:

Pertama, penerapan pasal 20 ayat 2 huruf b Undang-Undang Republik Indonesia Nomor 48 Tahun 2009 Tentang Kekuasaan Kehakiman yaitu kewenangan Mahkamah Agung untuk menguji peraturan perundang-undangan di bawah undang-undang termasuk PERMA.

Kedua, antinomi penerapan pasal 20 ayat 2 huruf b UndangUndang Republik Indonesia Nomor 48 Tahun 2009 Tentang Kekuasaan Kehakiman adalah pasal 10, pasal 1 angka (1), pasal 3 ayat (2), pasal 4 ayat (1), pasal 17 ayat (3), pasal 17 ayat (4), pasal 17 ayat (5) yang didalamnya mencakup asas asas nemo judex idoneus in propia causa dan asas ius curia novit. Selain itu, pasal 10, pasal 41 dan Pasal 42 (1) Undang-Undang Nomor 14 Tahun 1985 Tentang Mahkamah Agung juga menjadi antinomi penerapan pasal 20 ayat 2 huruf $b$ Undang-Undang Republik Indonesia Nomor 48 Tahun 2009 Tentang Kekuasaan Kehakiman. Namun, tidak saling meniadakan dan tidak dapat dipisahkan karena saling membutuhkan.

Kedua pernyataan diatas merupakan pernyataan yang menggambarkan sifat antinomi ketika Mahkmah Agung melakukan tugasnya yaitu melakukan uji materi peraturan perundang-undangan dibawah undang-undang (PERMA). Oleh karena itu, konsep harmonisasi sangat dibutuhkan untuk memperlancar pelaksanaan fungsi yang telah ditentukan pasal 20 ayat (2) huruf b UndangUndang Republik Indonesia Nomor 48 Tahun 2009 Tentang Kekuasaan Kehakiman tersebut.

Konsep harmonisasi tidak bisa dilepaskan dari peran hukum bagi kehidupan manusia. Hukum berperan sebagai pelindung kepentingan umum. Agar kepentingan setiap manusia bisa terjanim, maka hukum harus dijalankan. Pengamalan hukum dapat berlangsung secara normal dan damai, tetapi dapat terjadi juga karena pelanggaran hukum. Dengan hal demikian, hukum yang telah dilanggar harus ditegakkan. Melalui penegakan hukum inilah hukum itu menjadi kenyataan. Dalam penegakkan hukum terdapat 3 (tiga) unsur yang harus diperhatikan dan mendapatkan perhatian secara 
proporsional dan seimbang yaitu, kepastian hukum (rechtssicherheit), kemanfaatan (zweckmassigkeit) dan keadilan (gerechtigkeit). ${ }^{45}$

Secara konsepsional, inti dari penegakan hukum terletak pada aktivitas menyelaraskan hubungan nilai yang terurai di dalam kaidah-kaidah yang mantab dan sikap laku sebagai rangkaian penguraian nilai tahap akhir, untuk melahirkan, merawat dan menjaga kedamaian pergaulan hidup di dalam masyarakat. Penegakan hukum lebih menitikberatkan pada usaha-usaha untuk menyelaraskan atau menyamakan nilai-nilai yang berjalan di dalam masyarakat dengan nilai-nilai yang diuraikan dalam hukum. ${ }^{46}$ Tujuannya yaitu agar terwujud sikap laku atau pola perikelakuan yang sejalan dengan cita-cita pembentuk undang-undang. ${ }^{47}$

Berkaitan dengan kewenangan Mahkamah Agung untuk menetapkan peraturan dalam ini Parturan Mahkamah Agung (PERMA). Kehadiran PERMA sangat bermanfaat dalam menunjang jalannya praktik peradilan sehari-hari, karena terkadang undangundang belum selalu mengatur secara lengkap dan detail mengenai hal-hal yang dibutuhkan oleh praktik lembaga peradilan, sehingga perlu penjabaran lebih lanjut, khususnya mengenai hukum acara. ${ }^{48}$ Peraturan Mahkamah Agung merupakan bentuk kekuasaan administrasi dalam bidang legislasi Mahkamah Agung untuk mengatur dirinya sendiri.

Kekuasaan administrasi Negara dalam bidang legislasi, Menurut E. Utrecht, meliputi: pertama, kewenangan untuk membentuk peraturan atas inisiatif sendiri, terutama dalam menampung masalah-masalah yang belum ada peraturannya, tanpa harus menyandarkan pada pembuat undang-undang pusat; kedua, kekuasaan administrasi negara untuk membentuk peraturan atas dasar delegasi, karena pembentuk undang-undang pusat tidak mampu melihat setiap masalah-masalah yang timbul karena pembentuk undang-undang hanya bisa mengakhiri setiap detail pergaulan sehari-hari, pemerintah diberi tugas menyelaraskan

45 Sudikno Mertokusumo, Mengenal Hukum Suatu Pengantar, edisi kelima, cetakan pertama, (Yogyakarta: Liberty, 2003), hlm. 160

46 Soerjono Soekanto, Faktor-Faktor Yang Mempengaruhi Penegakan Hukum (Jakarta: Rajawali, 1983), 4.

47 Ronald S. Lumbuun, PERMA RI, Wujud Kerancuan Antara Praktik Pembagian $\mathcal{E}$ Pemisahan Kekuasaan (Jakarta: RajaGrafindo Persada, 2011), 59.

$48 \mathrm{Ibid}, 59$. 
peraturan-peraturan yang diciptakan pembentuk undang-undang pusat dengan kondisi yang sebenar-benarnya ada di masyarakat. ketiga, droit function yaitu kekuasaan administrasi negara untuk menafsirkan sendiri beragam peraturan, artinya administrasi negara berhak mengkoreksi hal aktivitas pembentuk undang-undang. ${ }^{49}$

Mahkamah Agung sebagai salah satu pelaku penyelenggara kekuasaan administrasi negara dalam bidang legislasi, berdasarkan delegasi kewenangan yang dilahirkan oleh undang-undang, Mahkamah Agung memiliki wewenang untuk melakukan ketiga hal tersebut sebagai sarana penegakan hukum. Hal ini dikarenakan, produk peraturan perundang-undangan selalu terlambat dibandingkan dengan perubahan aktivitas yang ada dalam kehidupan berbangsa dan bernegara. Di sisi lain, hakim/badan peradilan dilarang menolak untuk memeriksa, mengadili dan memutuskan suatu perkara yang dihadapkan kepadanya dengan dalih ketiadaan atau kurang jelasnya peraturan yang mengaturnya. selaras dengan inilah maka ada asas hakim dianggap tahu semua hukum (ius curia novit) yang menjadi dasar hakim harus mencari jalan keluar melalui penemuan hukum (rechtvinding).

Penemuan hukum menurut Donald L. Horowitz di dalam bukunya The Courts And Social Policy, secara nyata memiliki manfaat di dalam berkompetisi dengan perundang-undangan yaitu, bahwa penemuan hukum bekerja dengan kasus nyata dan berlaku secara umum setelah melalui proses trial and error dalam upayanya guna menghasilkan prinsip-prinsip hukum yang dapat dipraktikkan. Sementara perundang-undangan tidak lebih dari pernyataan kembali oleh pihak yang berwenang mengenai apa yang telah terlebih dahulu dialami oleh lembaga peradilan. ${ }^{50}$

Pengaturan yang dilakukan Mahkamah Agung seperti halnya Peraturan Mahkamah Agung dihadirkan sebagai solusi apabila ada peraturan perundang-undangan diatasnya itu memuat kekosongan maupun telah terlambat daripada perkembangan kebutuhan masyarakat, sehingga diduga sangat tepat apabila Mahkamah Agung

49 E. Utrecht, Pengantar Hukum Administrasi Negara Indonesia (Surabaya: Pustaka Tinta Mas, 1988), 11.

50 Donald L. Horowitz, The Court And Social Policy (Washington D.C.: The Bookings Institution, 1977), 3. 
melahirkan peraturan yang bersifat komplementer (complementary). ${ }^{51}$ Sifat komplementer diartikan sebagai penyempurna atau pelengkap terhadap perundang-undangan yang sudah ada. Artinya, Peraturan Mahkamah Agung tersebut tidak boleh merupakan suatu pengaturan yang berdiri sendiri tanpa ada sandaran dan cantolan kepada perundang-undangan yang berlaku. Oleh karena itu tidak dibenarkan bagi Mahkamah Agung untuk menerbitkan Peraturan Mahkamah Agung yang memuat tentang kebijakan umum yang tidak memiliki sandaran dan kaitannya dengan perundang-undangan yang telah dikeluarkan oleh DPR (legislatif) dan Presiden/pemerintah (eksekutif). ${ }^{52}$ Hal ini sesuai dengan pasal 5 jo. pasal 20 UUD 1945, Mahkamah Agung adalah kekuasaan kehakiman yang tidak memiliki kewenangan asli (original power) untuk membentuk peraturan perundang-undangan yang berkarakter kebijaksanaan umum, sebab kewenangan seperti itu ada di tangan DPR dan Presiden. ${ }^{53}$

Lantas, bagaimana kalo PERMA itu melanggar peraturan perundang-undangan di atasnya? Bukankah Mahkamah Agung sendiri yang akan menguji produknya sendiri? Apakah hal ini tidak akan muncul sebuah konflik kepentingan?

Penyelesaian permasalahan antinomi hukum tersebut adalah dengan mengunakan konsep harmonisasi hukum. Sehingga, dengan menggunakan konsep harmonisasi hukum, maka akan ditemukan alasan kebenaran bahwa Mahkamah Agung berhak untuk menguji PERMA meskipun PERMA merupakan produk dari Mahkamah Agung sendiri dan Mahkamah Agung dapat terhindar dari konflik kepentingan. Akibatnya, penerapan pasal 20 ayat 2 huruf b UndangUndang Republik Indonesia Nomor 48 Tahun 2009 Tentang Kekuasaan Kehakiman tidak menjadi sebuah problem untuk dilakukan oleh Mahkamah Agung. Alasan demikian didasarkan pada beberapa pernyataan yang dibangun berikut ini yaitu:

Pertama, asas kepentingan umum. Asas kepentingan umum dapat digunakan oleh hakim untuk menemukan hukum ketika peraturan perundang-undangan mengalami ketidakjelasan, kekosongan maupun peraturan perundang-undangan memberi

51 Lumbuun, PERMA RI, Wujud Kerancuan Antara Praktik Pembagian \& Pemisahan Kekuasaan, 30.

52 Ibid, 31.

53 Mahkamah Agung Republik Indonesia, Cetak Biru Pembaharuan Mahkamah Agung RI (Jakarta: Mahkamah Agung, 2003), 169. 
pilihan. Penggunaan asas ini sebagai konsekuensi untuk memberikan keadilan, kepastian dan kemanfaatan kepada masyarakat. Hal ini sejalan dengan pasal 5 Undang-Undang Republik Indonesia Nomor 48 Tahun 2009 Tentang Kekuasaan Kehakiman yang menjelaskan bahwa "hakim dan hakim konstitusi wajib menggali, mengikuti dan memahami nilai-nilai hukum dan rasa keadilan yang hidup dalam masyarakat."

Kedua, Asas ketatanegaraan. Struktur ketatanegaraan telah mengatur bahwa Mahkamah Agung yang mempunyai kewenangan untuk menguji peraturan perundang-undangan di bawah undangundang termasuk dalam hal ini PERMA dan tidak ada lembaga lain. Maka, hal ini menjadi dasar Mahkamah Agung untuk menguji PERMA. Selain itu, penggunaan kewenangan yang diberikan Mahkamah Agung berfungsi untuk menjaga keteraturan sistem ketatanegaraan yang telah diatur oleh konstitusi. Sehingga pengujian Peraturan Mahkamah Agung oleh Mahkamah Agung adalah konstitusional.

Implikasi kedua pernyataan tersebut diatas maka dapat menyimpangi asas hakim dilarang memeriksa perkara yang berkaitan dengan dirinya sendiri (nemo judex idoneus in propia causa) dan melaksanakan asas hakim dilarang menolak terhadap perkara yang diajukan kepadanya (ius curia novit). Sehingga, harmonisasi dapat ditempat sebagai sarana mengharmoniskan antinomi yang terjadi pada penerapan pasal 20 ayat 2 huruf b Undang-Undang Republik Indonesia Nomor 48 Tahun 2009 Tentang Kekuasaan Kehakiman. Dengan kata lain dapat dikatakan bahwa harmonisasi adalah sebuah konsep menggabungkan dua hal yang bertentangan untuk mencapai tujuan bersama. Hal ini sejalan dengan yang dijelaskan oleh Stammler" A just law aims at harmonizing individual purposes with that of society". Asas-asas hukum yang adil melingkupi harmonisasi antara kehendak, arah dan kepentingan perorangan, dengan kehendak, arah dan kepentingan umum. Kehendak dan arah serta kepentingan terdiri dari dua bagian, yaitu sama-sama menghormati dan partisipasi. ${ }^{54}$

\section{PENUTUP}

54 Slamet, Harmonisasi Hukum Dalam Perspektif Perundang-Undangan; Lex Specialis Suatu Masalah, 65. 
Berdasarkan argumentasi-argumentasi yang sudah dikemukakan dalam penelitian ini, maka dapat dirumuskan kesimpulan sebagai berikut:

Pertama, konstruksi antinomi dalam penerapan Pasal 20 Ayat 2 Huruf B Undang-Undang Republik Indonesia Nomor 48 Tahun 2009 Tentang Kekuasaan Kehakiman adalah pasal 10, pasal 1 angka (1), pasal 3 ayat (2), pasal 4 ayat (1), pasal 17 ayat (3), pasal 17 ayat (4), pasal 17 ayat (5) yang didalamnya mencakup asas asas nemo judex idoneus in propia causa dan asas ius curia novit. Selain itu, pasal 10, pasal 41 dan Pasal 42 (1) Undang-Undang Nomor 14 Tahun 1985 Tentang Mahkamah Agung juga menjadi antinomi penerapan pasal 20 ayat 2 huruf b Undang-Undang Republik Indonesia Nomor 48 Tahun 2009 Tentang Kekuasaan Kehakiman. Namun, tidak saling meniadakan dan tidak dapat dipisahkan karena saling membutuhkan

Kedua, konsep harmonisasi hukum dapat digunakan untuk menyimpagi sifat antinomi dalam penerapan Pasal 20 Ayat 2 Huruf B Undang-Undang Republik Indonesia Nomor 48 Tahun 2009 Tentang Kekuasaan Kehakiman. Konsep harmonisasi dihadirkan berdasarkan alasan yaitu adanya asas kepentingan umum dan asas ketatanegaraan.

\section{DAFTAR PUSTAKA}

A., Garner Bryan, ed. Black law dictionary. ST. Paul, Minn: West Group, 1968.

Andreae, Fockema. Kamus Istilah Hukum: Belanda-Indonesia. Cet. 1. Jakarta: Binacipta, 1983.

Apeldroon, L.j. Van. Pengantar Ilmu Hukum. Bandung: PT. Pradnya Paramita, 2001.

Asshiddiqie, Jimly. Perihal Undang-Undang. Jakarta: Rajawali Pers, 2010.

Attamimi, A. Hamid S. Teori Perundang-Undangan: Suatu Sisi Ilmu Pengetahuan Perundang-Undangan Indonesia yang Menjelaskan dan Menjernihkan Pemahaman. Pidato Pengukuhan Jabatan Guru Besar Tetap Pada Fakultas Hukum Universitas Indonesia. Jakarta, 1992. 
Atya. "Harmonisasi Hukum Internasional Pada Prinsip Common But Differentiated Resposnsibility Dalam Hukum Nasional, jurnal kosmik hukum." Jurnal Kosmik Hukum Volume 19, no. 1 (Januari 2019).

Fence M., Wantu. "Antinomi Dalam Penegakan Hukum Oleh Hakim." Mimbar Hukum, 3, Volume 19 (Oktober 2007).

Friedmann, W. Teori Dan Filsafat Hukum, Telaah Kritis Atas TeoriTeori Hukum. Penerjemah Arifin, M, Jakarta: Rajawali Pers, 1990.

Gandhi, L.M. "Harmonisasi Hukum Menuju Hukum yang Responsif." Makalah yang disampaikan pada Pidato Pengukuhan Guru Besar Tetap FH-UI, 1995.

Harahap, M. Yahya. Hukum Acara Perdata Tentang Gugatan, Persidangan, Penyitaan, Pembuktian dan Putusan Pengadilan. Jakarta: Sinar Grafika, 2016.

- - - Kekuasaan Mahkamah Agung Pemeriksaan Kasasi Dan Peninjauan Kembali Perkara Perdata. Cetakan pertama. Jakarta: Sinar Grafika, 2008.

Horowitz, Donald L. The Court And Social Policy. Washington D.C.: The Bookings Institution, 1977.

Hume, David. A Treatise Of Human Nature. Auckland: The Floating Press, 2009.

Indonesia, Mahkamah Agung Republik. Cetak Biru Pembaharuan Mahkamah Agung RI. Jakarta: Mahkamah Agung, 2003.

Kant, Immanuel. Critique Of Pure Reason. Cambridge: Cambridge University Press, 2010.

Kelsen, Hans. General Theory of Law and State. Cambridge, Massachusetts: Harvard University Press, 1949.

Lumbuun, Ronald S. PERMA RI, Wujud Kerancuan Antara Praktik Pembagian \& Pemisahan Kekuasaan. Jakarta: RajaGrafindo Persada, 2011.

Manan, Bagir. Hukum Positif Indonesia. Yogyakarta: FH UII Press, 2004. 
Mochtar, Zainal Arifin. "Antinomi Dalam Peraturan PerundangUndangan Di Indonesia." Jurnal Hasanuddin Law Review 1, no. issue 2 (Desember 2015).

Norrie, Alan. "From Critical to Social-Legal Studies: Three Dialectics in Search of a Subject." Journal Social and Legal Studies, no. 9 (2000). http://sls.sagepub.com/content/9/1/85.

Purbacaraka, Purnadi, dan Soerjono Soekanto. Ikhtisar Antinomi Aliran Filsafat Sebagai Landasan Filsafat Hukum. 1 ed. cet. 2. Jakarta: Rajawali, 1991.

Safudin, Endrik. Dasar-Dasar Ilmu Hukum. Malang: Setara Press, 2017.

- - - Pengantar Ilmu Hukum. Malang: Setara Press, 2020.

Setiadi, Elly M., dan Usman Kolip. Pengantar Sosiologi, Pemahaman Fakta Dan Gejala Permasalahan Sosial: Teori, Aplikasi Dan Pemecahannya. Cet ke II. Jakarta: Kencana Prenada Media Group, 2011.

Situmorang, Mosgang. "Harmonisasi Hukum Nasional di Bidang Korupsi Dengan United Nations Convention Against Corruption." Jurnal Rechtsvinding:Media Pembinaan Hukum Nasional Volume 3, no. 3 (Desember 2014).

Slamet, Kusnu Goesniadhie. "Harmonisasi Hukum Dalam Perspektif Perundang-Undangan." Jurnal Hukum volume 11, no. 27 (September 2004).

- - - Harmonisasi Hukum Dalam Perspektif PerundangUndangan; Lex Specialis Suatu Masalah. Surabaya: JP Books, 2006.

Soekanto, Soerjono. Faktor-Faktor Yang Mempengaruhi Penegakan Hukum. Jakarta: Rajawali, 1983.

Soepomo, R. Hukum Acara Perdata Pengadilan Negeri. Jakarta: Pradnya Paramita, 1993.

Suhartono. Harmonisasi Peraturan Perundang-Undangan Dalam Pelaksanaan Anggaran Belanja Negara (Solusi Penyerapan Anggaran Belanja Negara Yang Efisien, Efektif Dan Akuntabel). Tesis. Jakarta: Universitas Indonesia, 2011. 
Harmonisasi Hukum Dalam Antinomi Hukum...

Utrecht, E. Pengantar Hukum Administrasi Negara Indonesia. Surabaya: Pustaka Tinta Mas, 1988. 